\title{
Politikai változások a költségvetési kiigazítások tükrében
}

\begin{abstract}
A tanulmány 14 európai ország költségvetési konszolidációját tekinti át 1980 és 2014 között. Rövid elméleti kitekintést követően arra keresi a választ, hogy vannak-e negatív hatásai a kiadásoldali költségvetési kiigazításoknak a politikai folytonosságra nézve. Elemzi a konszolidációk legfontosabb vonásait, felhívja a figyelmet a módszertani nehézségekre, illetve azok jelentőségére a végső eredményt tekintve. Arra a következtetésre jut, hogy a költségvetési fegyelem sikeressége nem állítható szembe a politikai sikerességgel.

Journal of Economic Literature (JEL) kód: H12, H62, H870.
\end{abstract}

Ebben a tanulmányban a kiadásvezérelt költségvetési konszolidáció és a politikai folytonosság közti összefüggés szerteágazó témakörét egy speciális szemszögből közelítjük meg: 14 európai ország 1980 és 2014 között végrehajtott költségvetési kiigazítását vizsgáljuk meg. A mintában szereplő országok Ausztria, Belgium, Dánia, Finnország, Franciaország, Németország (1990 előtt NSZK), Írország, Olaszország, Hollandia, Portugália, Spanyolország, Svédország és Egyesült Királyság. Ez a fajta történeti megközelítés számottevő hasonlóságot mutat Alesina-Perotti [1995], [1996], von Hagen és szerzőtársai [2001], McDermottWescott [1996], Briotti [2004], Rzonca-Cizkowitz [2005] és Devries és szerzőtársai [2011] által követett módszerrel.

Alesina-Perotti [1996] 1960 és 1994 között 20 OECD-tagország mintegy 60 költségvetési kiigazítását elemezte. Empirikusan igazolták, hogy a költségvetési konszolidációk megítélésénél a számszaki követelmények mellett az egyes kiigazítások összetétele, a kiigazítási csomag tartalma is meghatározó szerepet játszik. Ugyanígy fontos megállapításuk, hogy az árfolyam-leértékelődés nem rendelhető egyértelmüen a sikeres vagy sikertelen konszolidációkhoz. Ezek a következtetések az európai országok 1990-es években végrehajtott kiigazításaira is helytállónak bizonyultak (von Hagen és szerzőtársai [2001]). Briotti [2004] a deficitcsökkentés államháztartási kiadási szerkezetére gyakorolt hatásának részletes vizsgálata kapcsán

Asztalos Viktor a Nemzetgazdasági Minisztérium munkatársa.

A kézirat első változata 2015. április 22-én érkezett szerkesztőségünkbe.

DOI: http://dx.doi.org/10.18414/KSZ.2015.11.1196 
jutott arra, hogy amennyiben egy országnak gyors ütemű költségvetési konszolidációt kell végrehajtania, úgy a strukturális reformok helyett az adóemelések, illetve a különböző átmeneti intézkedések kerülnek elötérbe. McDermott-Wescott [1996] 20 országot átfogó tanulmányának az a következtetése, hogy azok a kiigazítások vezetnek gyorsabb növekedéshez, amelyek a kiadások csökkentésére helyezik a hangsúlyt. Mindezt Rzonca-Cizkowitz [2005] azzal egészítette ki, hogy a szerkezeti átalakításokkal végrehajtott költségvetési konszolidáció a korábban feltételezettnél rövidebb időn belül képes hozzájárulni a gyorsabb gazdasági növekedés eléréséhez. Devries és szerzőtársai [2011] a döntéshozók felől vizsgálták a költségvetési kiigazításokat. Az áttekintett empirikus vizsgálatok alapján egyrészt meghatározónak bizonyult a döntéshozók fenntartható pénzügyek iránti igénye, másrészt az a motívum, hogy ily módon érdemben képesek befolyásolni a belföldi kereslet alakulását. Összességében: ha a felsorolt konszolidációs megfigyeléseket egymás mellé rendezzük, az a kép rajzolódik ki, hogy a fenntarthatatlan költségvetési pálya a kiigazítások szükségszerűségét vetíti előre, ami azonban egy többváltozós egyenlet (AlesinaPerotti [1995]). További észrevétel, hogy a releváns következtetések levonásához elengedhetetlen a költségvetési és politikai feltételek körültekintő meghatározása.

\section{Módszertani alapvetések}

A költségvetési folyamatok értékelése többféle szempont szerint, különböző időhorizontokon végezhető. ${ }^{1}$ A szakirodalomban nincs általános definíciója a kiigazításra szoruló deficitszintnek, illetve a konszolidációs folyamat egyéb jellemzőinek (a konszolidáció időtartama, az egyenlegjavulás mértéke stb.). ${ }^{2}$ McDermott-Wescott [1996] az elsődleges strukturális egyenleg több mint két éven át tartó legalább másfél százalékpontos javulását tekinti mérvadónak. Alesina-Ardagna [1998] és Alesina és szerzötársai [2002] szerint a konszolidáció definíciója az elsődleges strukturális egyenleg évenként legalább másfél százalékpontos vagy két év alatt legalább két százalékpontos javulása. Mások az eredményszemléletű egyenlegre vonatkozóan fogalmazzák meg a kiigazítás legfontosabb követelményeit (MNB [2006]). Aligha kétséges, hogy a likviditás biztosítása szempontjából megkerülhetetlen szerepe van a pénzforgalmi hiánynak, miközben az sem lehet vita tárgya, hogy a strukturális egyenleg nélkül nem adható reális helyzetértékelés egy ország hosszabb távú költségvetési és gazdasági folyamatairól (Hoffmann-P. Kiss [1999]).

Jelen írás a költségvetési konszolidációk vizsgálata során mégis a szakirodalom által meghatározónak tekintett eredményszemléletű egyenlegmutatót használja, ami a maastrichti feltételek teljesítése, illetve a stabilitási és növekedési paktum elöírá-

\footnotetext{
${ }^{1}$ Fontos megemlíteni, hogy a kormánytisztviselők számára a költségvetés közvetlen területén kívül számos egyéb eszköz (például szabályozás) is rendelkezésre áll, hogy elképzeléseiket megvalósíthassák, (lásd erről bővebben például Tanzi [1995] munkáját).

${ }^{2}$ A költségvetési kiigazítások általános definíciójának különböző jellemzőit Giudice és szerzőtársai [2003] vette számba.
} 
sai szempontjából releváns hiányszám. ${ }^{3}$ A forrásokat tekintve az Európai Bizottság és a Nemzetközi Valutaalap által közzétett statisztikai információkra támaszkodik. A tanulmány mindezen elméleti okfejtéseket követően azokat a költségvetési konszolidációkat tekinti át, amelyeknél:

1. a költségvetési hiány mélypontja a vizsgált periódusban elérte a GDP legalább 3 százalékát,

2. a kiigazítás első három évében legalább a GDP 1,5 százalékpontját elérő egyenlegjavulás következett be,

3. a kiigazítás közben nem volt jelentősebb, a GDP 1 százalékpontját elérő viszszaesés,

4. a kiigazítás a költségvetési konszolidáció időtartama alatt döntően (legalább 50 százalékos mértékben) a költségvetés kiadási oldalát érintette.

A költségvetési konszolidáció okait tekintve az egyes országokról elénk táruló kép számos hasonlóság mellett szembetűnő különbséget is mutat. Ez egyrészt a problémák eltérő jellegéből adódik - komoly ingatlanár-emelkedés például olykor rendkívül meghatározó az érintett ország gazdaságpolitikai lehetőségeinek leszűkülésében, míg másoknál ez csupán származékos kockázat. Másrészt számottevő lehet a különbség abban a tekintetben is, hogy az érintett ország milyen fajsúlyú problémával küszködött, esetleg a befektetők pánikreakciója nagyobb volt-e az indokoltnál - a befektetők időnként hajlamosak erős túlzásokba esni. Az elemzés ezen oksági viszonyok feltárását nem tekinti céljának. Mivel ezek a kérdések szétfeszítenék a tanulmány kereteit, fontosságukra csak utalni tudunk. ${ }^{4}$ Arra azonban törekszünk, hogy - alapvetően leíró jelleggel - bemutassuk a költségvetési folyamatok mellett a főbb makrogazdasági mutatók (reálnövekedés, infláció, munkanélküliség, külső egyensúly) alakulását.

A költségvetési konszolidáció kereteinek rögzítése mellett szükséges a politikai folytonosság kritériumának meghatározása is. Az európai országok politikai térképéről Nohlen-Stöver [2010] müve nyújt kiváló áttekintést. Számos módszertani problémát rejt a kiigazítás hozzáillesztése a politikai menetrendhez. Elsősorban a költségvetési konszolidáció kezdete nem feltétlenül esik egybe a parlamenti ciklus kezdetével. ${ }^{5}$ Másodsorban fontos annak eldöntése, hogy a költségvetési konszolidációnak milyen időtávon van hatása a politikai életre. Tekintettel arra, hogy elemzésünkben a kiigazítások és a politikai foly tonosság együttmozgását vizsgáljuk, a két időpont nem térhet el jelentősen egymástól. Harmadsorban módszertani dilemmát okoz, hogy többpárti koalíció esetén az adott koalíció fennmaradását, esetleges bővitését tekintjük-e mérvadónak, vagy kizárólag a koalíció fö politikai erejének kormányzati pozícióban maradását. Elemzési

\footnotetext{
${ }^{3}$ Hangsúlyoznunk kell, hogy bár a definíció kerete a legtöbb esetben azonos, a kritériumok számottevően eltérnek. Ezt egyrészt a vizsgálódás tárgyának különbözősége, másrészt a megfelelő esetszámra való törekvés okozza. Jelen írás nem foglalkozik részletesen a költségvetés kiadási oldalának összetevőivel (erről lásd bővebben például Kármán [2008], Szemere-P. Kiss [2011]).

${ }^{4}$ A növekedés és hiánycsökkentés mélyebb összefüggéseire bővebben is utal például Perotti [1996], Alesina és szerzőtársai [1998], CEMI [2006].

${ }^{5}$ Különösen érdekes az NSZK példája. A kormányfőcserére a koalíciós kormány felbomlása miatt (Helmut Kohl kormányfövé választása 1982-ben) a parlamenti ciklus közepén került sor, a költségvetési intézkedések csak ezután következtek.
} 
szempontból ez utóbbi tünik relevánsnak, hiszen a kormányzati politikát leginkább a kormányfö, illetve a kormányfót adó párt irányvonala határozza meg.

Mindezeket figyelembe véve az elemzési mintánkban maradt országokat a költségvetési konszolidáció után három fő dimenzió szerint vizsgáljuk:

1. a kiigazítás első évétől melyik párt adta a kormányföt,

2. a kiigazítás időszakában a kormányfő pártja képes volt-e megtartani a kormányfói pozíciót az újabb parlamenti ciklus után, illetve

3. a kiigazítást követő második év végéig a kormányfő pártja meg tudta-e tartani a kormányfői pozíciót az újabb parlamenti ciklus után.

A tanulmány nem vizsgálja, hogy a szóban forgó szempontoknak megfelelően kiigazító országok politikai helyzete miben tér el és miben hasonlít. Kizárólag arra törekszik, hogy bár korlátozó feltételek mellett, de lehetővé tegye bizonyos gazdaságpolitikai következetések levonását.

\section{A kiigazítások költségvetési vonásai}

A költségvetési konszolidációk döntően a nyolcvanas és kilencvenes években zajlottak le a nyugat- és dél-európai országokban. Ebben a piac fegyelmező ereje mellett szerepet játszottak közösségi szinten létrejött költségvetési előírások is - feltételeink között szerepelt, hogy a költségvetési hiány mélypontja a vizsgált periódus alatt érje el a GDP legalább 3 százalékát. Az európai gazdaságok a következő évtized elején csak csekély lendületet vesztettek (2001-2003), komolyabb növekedési megrázkódtatás nem érte őket. A 2008-as külső sokk időszakában pedig a költségvetési fegyelem a legtöbb ország számára már nem bizonyult első számú célnak. Ebben az időszakban a globális válság okozta gazdasági problémák tompítása miatt jellemzővé vált az állami túlköltekezés, majd az ezt követő elhúzódó válságkezelés.

A költségvetési kritériumok alapján 23 döntően kiadás oldali kiigazítást tudtunk beazonosítani; az elemzési mintába bevont 14 országból 10 ország volt érintett (1. táblázat).

A krónikusan magas költségvetési hiánnyal rendelkező országok (Belgium, Írország, Olaszország, Portugália) a kilencvenes évek közepéig több alkalommal is átestek költségvetési konszolidáción. Mivel ezek az országok a kilencvenes években a monetáris unióhoz való csatlakozás mellett döntöttek, a konszolidáció megindítására a válságperiódusoktól függetlenül is sort kellett keríteniük. Többek között a sorozatos kiigazításoknak köszönhető, hogy míg az elemzési mintába bevont országok átlagos deficitszintje 1980-1994 között a GDP 4,5 százaléka körül alakult, az átlagos hiány mértéke a következő tíz évben a GDP 1,5 százaléka alá süllyedt. ${ }^{6}$ A globális válság elmélyülése következtében ez a szám némileg megemelkedett: 2005 és 2014 között a GDP 3 százalékát tette ki.

\footnotetext{
${ }^{6}$ Vizsgálatunknak nem tárgya, de a kilencvenes évek második felétől zajló időszak két markánsan eltérő periódusra osztható. Az átlagos hiánycsökkenés az 1995-2000 közötti periódusban folyamatos és nagymértékű volt, az elemzési mintába bevont országok 2000-ben a GDP 1,6 százalékát kitevő költségvetési többletet értek el. Ez azonban az évtized közepére romló tendenciát mutatva a GDP 1,5 százalékát kitevő deficitre változott.
} 
1. táblázat

Költségvetési konszolidációk az európai országokban, 1980-2014

\begin{tabular}{|c|c|c|}
\hline & \multicolumn{2}{|c|}{ Költségvetési deficit mélypontja } \\
\hline & összes (36) & döntően kiadásoldali (23) \\
\hline Ausztria & $1987,1995,2004,2009$ & $1987,1995,2004,2009$ \\
\hline Belgium & 1983,1992 & 1983,1992 \\
\hline Dánia & 1982 & \\
\hline Egyesült Királyság & $1984,1993,2009$ & 1984, 1993, 2009 \\
\hline Finnország & 1993 & 1993 \\
\hline Franciaország & 1993, 2003, 2009, & \\
\hline Hollandia & $1982,1995,2003,2009$ & 1982,1995 \\
\hline Írország & 1985,2010 & 1985,2010 \\
\hline Luxemburg & - & \\
\hline Németország & $1981,1995,2003,2010$ & $1981,1995,2003$ \\
\hline Olaszország & $1985,1991,2009$ & \\
\hline Portugália & $1981,1986,1993,2010$ & 1986, 1993 \\
\hline Spanyolország & 1985,1993 & 1993 \\
\hline Svédország & $1982,1985,1993$ & $1982,1985,1993$ \\
\hline
\end{tabular}

Definíciók

Költségvetési deficit mélypontja: a költségvetési hiány mélypontja a vizsgált periódus alatt elérte a GDP legalább 3 százalékát.

Egyenlegjavulás: a kiigazítás első három évében legalább a GDP 1,5 százalékpontját elérő egyenlegjavulás következett be.

Kiigazítás közbeni visszaesés: a kiigazítás közben nem volt jelentősebb, a GDP 1 százalékpontját elérő visszaesés.

Döntően kiadásoldali kiigazítás: a kiigazítás a költségvetési konszolidáció időtartama alatt döntően (legalább 50 százalékos mértékben) a költségvetés kiadási oldalát érintette.

Forrás: Nemzetközi Valutaalap, Európai Bizottság.

A kiigazítások szerkezetét elemezve a kiadások csökkentése sokkal meghatározóbb volt a költségvetési konszolidációk során. Ugyanakkor különösen a korai időszakban egyes országok (Dánia, Olaszország, Portugália, Spanyolország) a bevételek növelésével próbálták megteremteni a költségvetés egyensúlyát. Mivel a szóban forgó országok többségében magas volt az újraelosztási ráta, ez a konszolidációs időszak során negatívan befolyásolta a növekedési kilátásokat. Ezzel szemben a kiadásvezérelt kiigazításoknál megfigyelhető, hogy a hiányszűkítés időszakában időnként a GDP-arányos bevételek még csökkentek is (például Ausztria, Spanyolország).

A kiigazítások döntően „orrnehezek” voltak. A kiadásvezérelt kiigazításoknál az első két évben átlagosan a költségvetési konszolidáció közel háromnegyedét végrehajtották. A legkisebb, 4,6 százalékos mértékü kiigazítás Spanyolországban (1993), 
a legnagyobb, 121,4 százalékos mértékű Svédországban (1982) volt. ${ }^{7}$ Öt országban - Ausztria (1987, 1995, 2004), Belgium (1983), Németország (1995), Írország (2010) és Hollandia (1995) - már a konszolidációs periódus első évében megvalósult a kiigazítás több mint 50 százaléka, vagyis a vizsgált országok közül több példát is találunk a rövid ideig tartó drasztikus kiigazításra. Ennek kapcsán érdemes megjegyezni, hogy minél eröteljesebben összpontosult a költségvetési konszolidáció a kiigazítási periódus első szakaszára (például Belgium, Németország), annál nagyobb lett a hiánycsökkentés mértéke. ${ }^{8}$

\section{A kiigazítások makrogazdasági vonásai}

A kiadásvezérelt kiigazításoknál a GDP növekedési üteme már a konszolidáció indulását követő első évben jelentősen megemelkedett: a 23 válságepizódból 15 esetben történt javulás. Bár a költségvetési deficit mélypontjának idején a növekedés relatíve széles sávot ölelt fel, a 4,3 százalékos csökkenéstöl a 3,8 százalékos emelkedésig (1. ábra), ez főképp egy-két esetnek volt köszönhető. Amennyiben a kiugróan szélsőséges növekedési adatoktól eltekintünk, a viszonyítási pont jóval szűkebb sávban szóródik: a gazdaságok a mínusz 1,3 százalék és a plusz 2,3 százalék között teljesítettek. Az országok többségében a szóban forgó szintről a gazdaság egyenletesen gyorsult fel, ez alól csak néhány ország a kivétel (Írország, Spanyolország, Egyesült Királyság). Ausztria 1996-ban induló kiigazítása a tekintetben egyedi volt, hogy az ország növekedési üteme csupán a konszolidáció harmadik évében tudta meghaladni az induló ütemet.

A kiigazítást kísérő dinamikus növekedésben a külső konjunktúra is meghatározó szerepet játszott. Az európai gazdaságok a világgazdasági trenddel való együttmozgása csupán a nyolcvanas évek elején és az 1992-1993-as válság során lazult fel (2. ábra). Mivel erre az időszakra esett a hiánycsökkentési periódusok többsége, ez kedvezőtlenül befolyásolta a bajba jutott országok gazdaságpolitikai mozgásterét.

Az infláció relatíve alacsony, öt százalék körüli átlagszintröl indulva a konszolidáció időtartama alatt három százalék alá mérséklődött (3. ábra). Míg a kiigazítás kezdetén 23 kiigazítási epizódból 11 alkalommal haladta meg a szóban forgó háromszázalékos értéket, addig a kiigazítási periódus végén öt ilyen epizód maradt (2. táblázat). $\mathrm{Az}$ is megfigyelhető, hogy a konszolidáció időszakában nem történt drámai változás a fogyasztói árindex emelkedését tekintve, illetve a legtöbb országban fokozatosan közelített a drágulás mértéke a háromszázalékos tartományhoz. A nyolcvanas években lezajlott portugál kiigazítás több tekintetben is kilóg a konszolidációk sorából. Az ország rendkívül magas fogyasztói árindexe (19,3 százalék) nemzetközi összevetésben is jelentős volt, s ugyan a vizsgált periódusban a legnagyobb mértékben mérséklödött, a konszolidáció végeztével még így is a legmagasabb szintet (12,6 százalék) érte el.

\footnotetext{
${ }^{7}$ Kizárólag Svédországban (1982) és Ausztriában (1995) haladta meg a kiigazítás üteme az első két évben a 100 százalékot a megadott költségvetési feltételek mellett.

${ }^{8}$ Fontos hangsúlyozni, hogy nemzetközi tapasztalatok szerint többnyire az a sikeres kiigazítás, amely „orrnehéz”, azaz a növekedés feltételeit mielőbb képes helyreállítani (Lámfalussy [2008]).
} 


\section{1. ábra}

Növekedési ütem a kiigazító országokban (százalék)

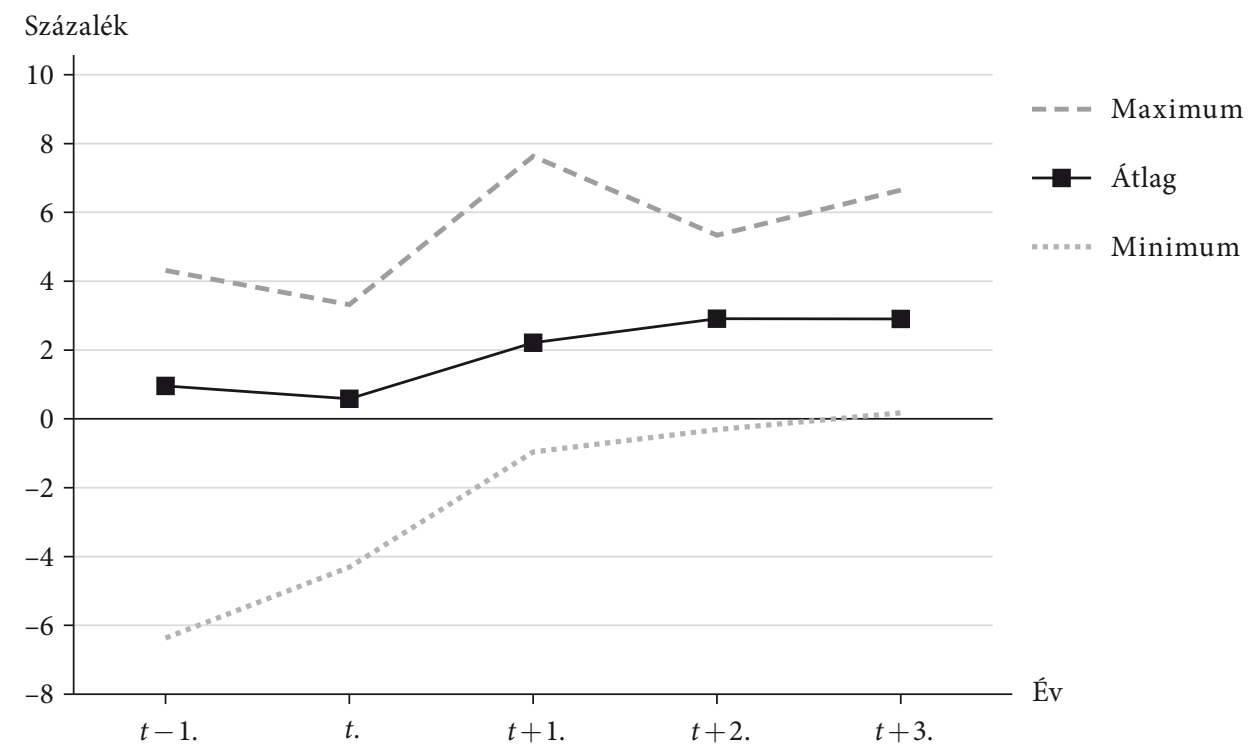

Megjegyzés: a $t$. év a költségvetési hiány mélypontja, a $t-1$. év a költségvetési hiány mélypontját megelőző év, a $t+1$. év a kiigazítás első éve; a $t+2$. év kiigazítás második éve, a $t+3$. év a kiigazítás harmadik éve.

Forrás: Nemzetközi Valutaalap, Európai Bizottság.

\section{2. ábra}

Növekedési ütem az Európai Unióban és a világgazdaságban (százalék)

\section{Százalék}

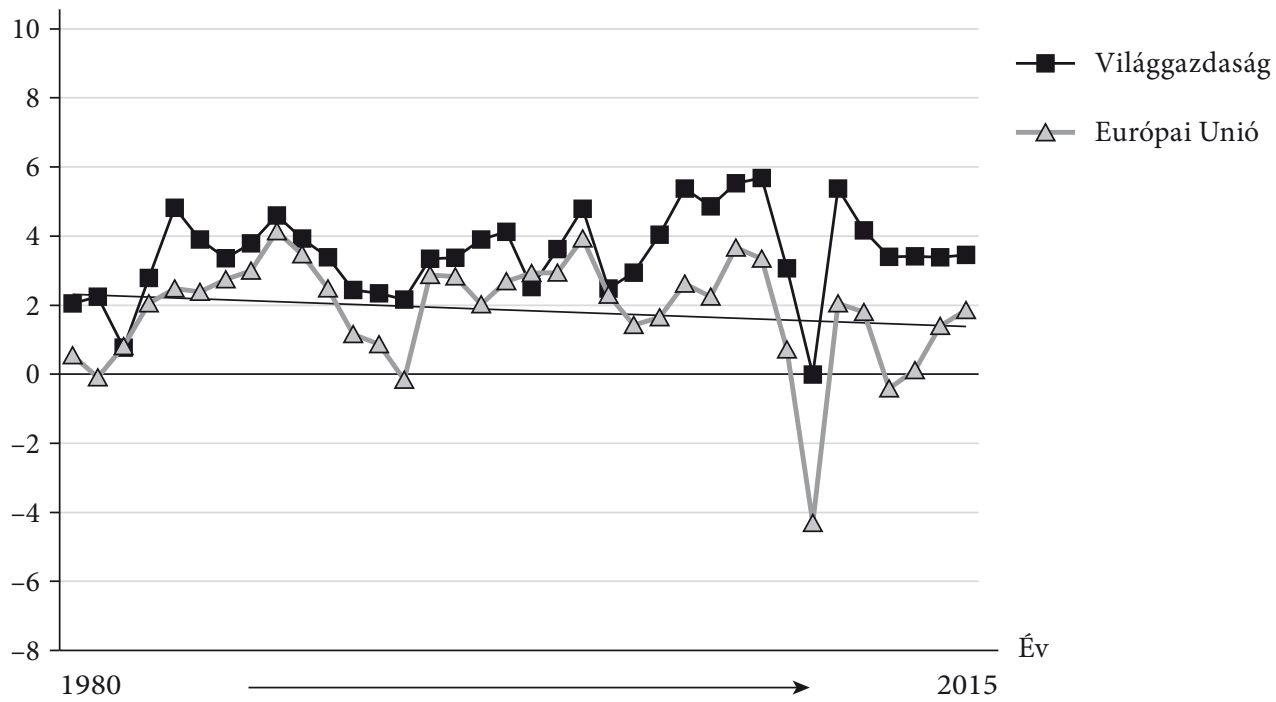

Forrás: Nemzetközi Valutaalap, Európai Bizottság. 
3. ábra

Az infláció alakulása (százalék)

Százalék

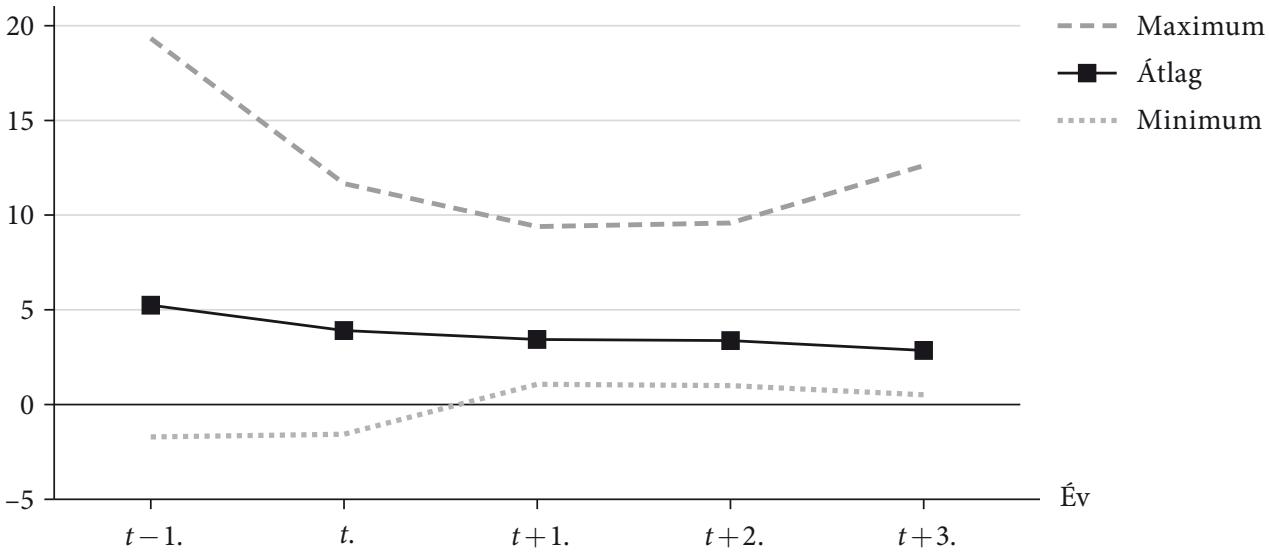

Megjegyzés: a $t$. év a költségvetési hiány mélypontja, a $t-1$. év a költségvetési hiány mélypontját megelőző év, a $t+1$. év a kiigazítás első éve; a $t+2$. év a kiigazítás második éve, a $t+3$. év a kiigazítás harmadik éve.

Forrás: Nemzetközi Valutaalap, Európai Bizottság.

2. táblázat

A háromszázalékos infláció teljesülése a kiigazító országokban

\begin{tabular}{lcc}
\hline & \multicolumn{3}{c}{ Periódus } \\
\cline { 2 - 3 } & $t$. & $t+3$. \\
\hline Ausztria & ++++ & ++++ \\
Belgium & + & ++ \\
Egyesült Királyság & ++ & ++ \\
Finnország & + & + \\
Hollandia & + & ++ \\
Írország & + & ++ \\
Németország & ++ & +++ \\
Portugália & - & + \\
Spanyolország & - & + \\
Svédország & - & + \\
Összesen & 12 & 18 \\
\hline
\end{tabular}

Megjegyzés: a + jelek száma a kiigazítások számosságára utal. A krízisepizódok száma: 23. Forrás: Nemzetközi Valutaalap, Európai Bizottság.

A kilencvenes években két tényező szerepe korlátozta az infláció növekedését. Egyrészt a monetáris unióhoz való csatlakozás szigorú követelményként fogalmazta meg az árstabilitás elérését, illetve a fogyasztói árindex relatíve alacsony szintre szorítását. Másrészt 
az euró bevezetésével mérséklődtek a hazai monetáris hatóság ez irányú lehetőségei. A 2008-as külső sokk egyik származékos hatása abban mutatkozott meg, hogy az árak csak rendkívül korlátozottan gyarapodtak a kiigazítás időtartama alatt.

A munkanélküliségi ráta minimálisan csökkent a konszolidációs időszakban, ez a csökkenés azonban nem egyformán jellemezte az egyes válságepizódokat. Az esetek mintegy kétharmadában sikerült lejjebb szorítani a munkanélküliséget, ugyanakkor arra is találunk példát, hogy a munkanélküliségi ráta igen jelentősen megemelkedett a konszolidációs folyamat végére [például Németország (1982), Belgium (1992)]. Ebben a tekintetben kulcsévnek tűnik a kiigazítás első éve. Amennyiben már a konszolidációs időszak kezdetén sikerült mérsékelni a munkanélküliséget, akkor a kiigazítás teljes hosszában lehetővé vált annak visszaszorítása (4. ábra).

\section{4. ábra}

A munkanélküliségi ráta alakulása a konszolidációs időszak végére (százalékpont)

a) Krízisepizódok, amelyeknél csökkent

Százalékpont

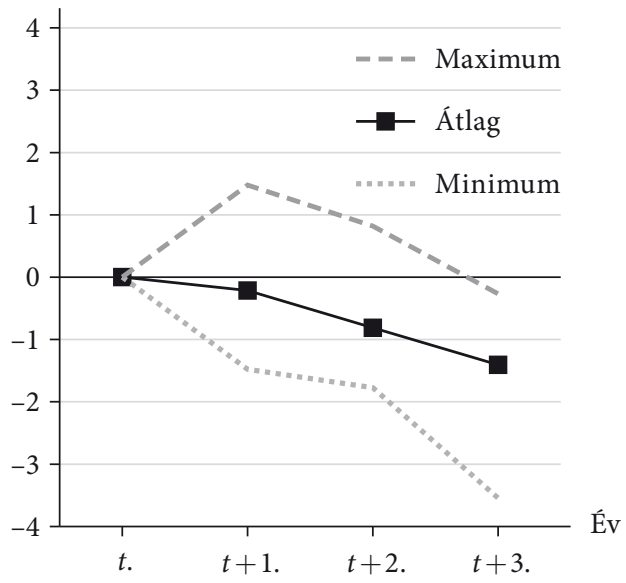

Krízisepizódok száma: 14

Kezdeti időszak $(t$.): 100 százalék

Átlagcsökkenés: 1,4 százalékpont b) Krízisepizódok, amelyeknél nőtt

Százalékpont

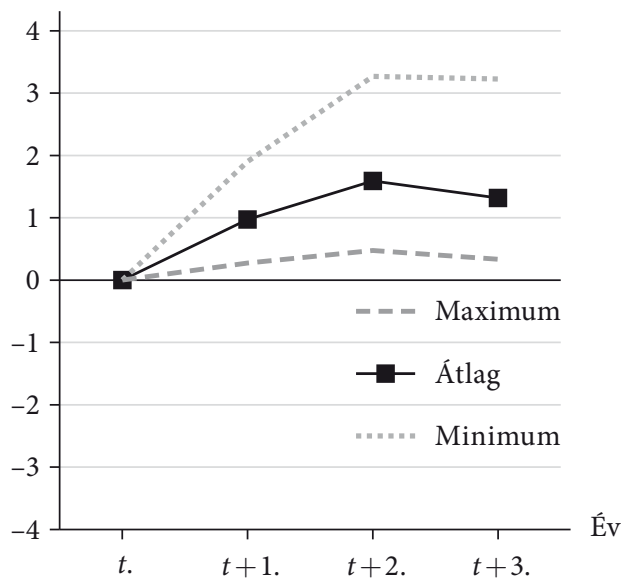

Krízisepizódok száma: 9

Kezdeti időszak $(t$.$) : 100$ százalék

Átlagnövekedés: $\quad 1,3$ százalékpont

Forrás: Nemzetközi Valutaalap, Európai Bizottság.

A munkanélküliségi ráta csökkenésében az egyes országok induló foglalkoztatottsági szintje nem töltött be meghatározó szerepet. A hagyományosan magas foglalkoztatottsági rátával bíró országokban, Hollandiában és Svédországban a konszolidáció időtartama alatt is tudott bővülni a munkavállalók száma, amit a munkanélküliségi ráta csökkenése kísért. Míg ugyanezen periódusban az alacsonyabb foglalkoztatottsági rátával bíró spanyol gazdaságban a foglalkoztatottság kismértékű visszaesése (az 1993-as kiigazítás mintegy 100 ezer fös csökkenéssel járt) volt megfigyelhető.

A munkapiaci események több ágon keresztül is segíthetik a deficitcsökkentés folyamatát. Egyrészt a foglalkoztatottak számának bővülése növekvő adó- és 
járulékbevételhez juttatja a költségvetést, így szűkíti a hiányt. Másrészt a munkanélküliek számának csökkenése az államháztartás kiadás oldalán okozhat megtakarítást, ami úgyszintén a kisebb deficit irányába hat. Mivel a vizsgált kiigazítások mintegy felében a munkanélküliségi ráta különbsége a konszolidáció legelső és legutolsó éve között csekély mértékű volt (egy százalékponton belüli), ez a tényezö vélhetően nem gyakorolt érdemi hatást a költségvetés egyenlegére.

A külső finanszírozási pozíció tekintetében kevés válságepizód (Írország, Finnország, Portugália) kivételétől eltekintve nem történt jelentős elmozdulás. A kiigazítási időszak kezdetét jellemző enyhe finanszírozási igény az átlagmutató folyamatos növekedése mellett mérsékelt finanszírozási képességgé változott a kiigazítási időszak végére (5. ábra). Ennek fényében nem meglepö, hogy többségben voltak azok a válságepizódok, amelyek esetében a konszolidációs időszakban csökkenhetett az ország külső forrásokra való ráutaltsága: a 23 esetből 16 esetben.

5. ábra

A folyó fizetési mérleg alakulása (a GDP százalékában)

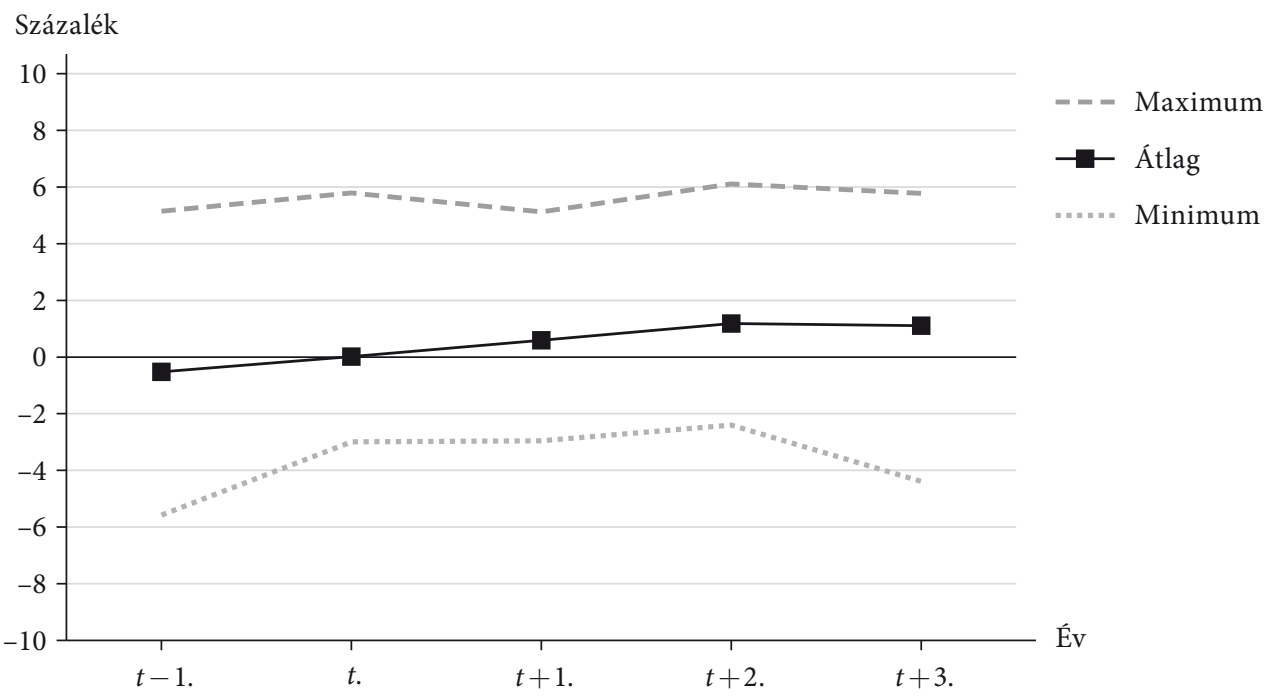

Forrás: Nemzetközi Valutaalap, Európai Bizottság.

Az egyes jövedelemtulajdonosok helyzetét tekintve jól kimutatható „átváltás” figyelhető meg az állami szféra és a magánszektor között (6. ábra). A jelentős költségvetési deficitcsökkentést ugyanis csupán kismértékü folyó fizetésimérleg-javulás kísérte, vagyis a magánszektor jelentős részben ellensúlyozta az államháztartási hiány viszszahúzódását. Másképp fogalmazva: az állami szektor rossz allokációját felváltotta a piaci szereplök növekedési ütem felgyorsulásához - minden bizonnyal - jobban illeszkedő magatartása (lásd fentebb a növekedési részt). Amennyiben a válságot megelőző deficitfelhalmozó időszakot tekintjük, ugyanez az összefüggés ellentétes elöjellel áll fenn: a költségvetési hiány megugrása az esetek döntő többségében a magánszektor növekvő megtakarítása mellett valósult meg. 
6. ábra

Az állam finanszírozási igénye (a GDP százalékában)

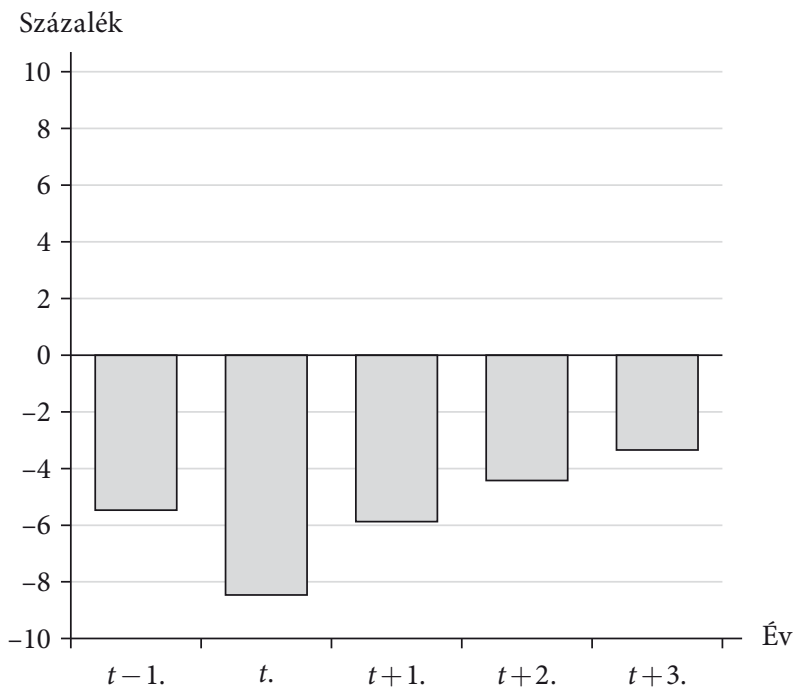

Forrás: Nemzetközi Valutaalap, Európai Bizottság.

A kiadásvezérelt kiigazítások közül csak minden harmadik indult pozitív külső fizetési pozícióval, vagyis meglehetősen gyakori volt az ikerdeficit a vizsgált országok körében. Az elemzett epizódok közül Portugáliát (1993) és az Egyesült Királyságot (2009) jellemezte, hogy a kiigazítási időszak végére relatíve magas, a GDP 3 százalékát meghaladó külső finanszírozást igényelt. Mindkét ország esetében a konszolidáció harmadik évében érték el a kiigazítási periódus legmagasabb külső finanszírozási igényét.

\section{Költségvetési egyenleg és a politikai változások}

A politikai szempontot elemezve, a vizsgált válságepizódok többségében a kormány a hivatalba lépése második évében kezdte el a költségvetési deficit leszorítását (3. táblá$z a t)$. E tekintetben nem észlelhető jelentős eltérés a különböző évtizedek között, azonban a nyolcvanas évek konszolidációit vizsgálva látszik némi eltolódás a politikai ciklus első fele irányába. A nyolcvanas években lezajlott tíz kiigazításból nyolcra már a ciklus első két évében sor került. ${ }^{9}$ Egy másik csoportosítás szerint a kormány hivatalba lépésénél az egyes országok krízisepizódjai meghatározóak. Ebből a szempontból szemlélve a több konszolidáción átesett országoknál jellemzően nem állapítható meg a kiigazítási időszak pontos kezdete. Mindössze Ausztria és Írország esetében figyelhető meg, hogy kiigazításuk a kormányalakításhoz képest mindig ugyanarra az időszakra esett.

\footnotetext{
${ }^{9}$ Hangsúlyozni kell az „év” kapcsán, hogy az naptári évet jelent. Ebből fakadóan az egyes országok vonatkozásában az időtartamot tekintve akár jelentős különbségek is lehetnek. Például van olyan ország, amelynél az év elején lép hivatalba a kormány, s van olyan, amelynél az év második felében.
} 


\section{3. táblázat}

Kiadásvezérelt kiigazítások és a politikai változások

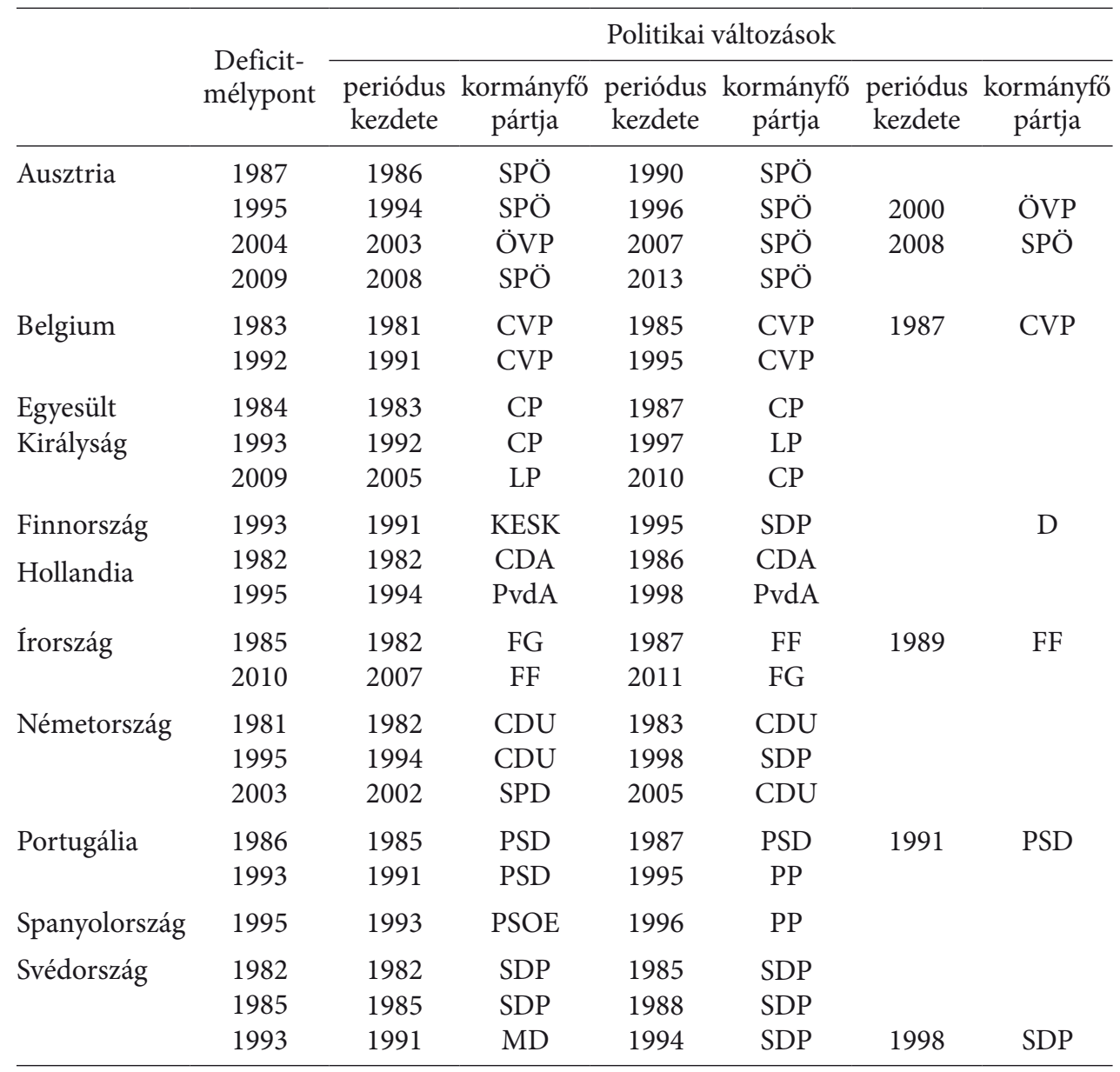

Definíciók

Intervallum kezdete: a kormányfö, illetve pártja hivatalba lép a konszolidáció megindulása előtt. Kiigazítás időszaka: a kiigazítás időszakában bekövetkező újabb parlamenti ciklusban a kormányfö pártja képes-e megtartani hivatali pozícióját.

Intervallum vége: a kiigazítás után legfeljebb a második év végéig az újabb parlamenti ciklusban a kormányfö pártja képes-e megtartani hivatali pozícióját.

Rövidítések

Ausztria: SPÖ - Szociáldemokrata Párt, ÖVP - Osztrák Néppárt; Belgium: CVP - Kereszténydemokrata Párt; Egyesült Királyság: CP - Konzervatív Párt, LP - Munkáspárt; Finnország: KESK - Centrumpárt, SDP - Szociáldemokrata Párt; Hollandia: CDA - Kereszténydemokrata Tömörülés, PvdA - Szociáldemokrata Munkapárt; Írország: FG - Egyesült Írország Pártja, FF - A végzet katonái; Németország: CDU - Kereszténydemokrata Unió, SPD - Szociáldemokrata Párt; Portugália: PSD - Szociáldemokrata Párt, PS - Szocialista Párt; Spanyolország: PSOE - Spanyol Szocialista Munkáspárt, PP - Néppárt; Svédország: SDP - Szociáldemokrata Párt, MP - Mérsékelt Párt.

Forrás: Nemzetközi Valutaalap, Európai Bizottság, Nohlen-Stöver [2010]. 
Az elemzett válságepizódok között viszonylag alacsony számba fedezhető fel déli ország. Egyrészt az újraelosztási ráta ezekben az országokban nem feltétlenül indokolta a költségvetés döntően kiadási oldalát érintő kiigazítást, ellentétben például a skandináv országokkal. Másrészt az érintett országok kormányai a szóba jöhető megoldások közül nem a kiadási tételek visszaszorítását preferálták, hanem feltételezhetően politikai bátorság hiányában a bevételek növelésével próbálták biztosítani a költségvetés egyensúlyát. Amint az 1. táblázatból is kiderül, a kiigazítások számosságát tekintve lényegi különbség nem tapasztalható az egyes országcsoportok között.

A konszolidációk levezénylése során túlsúlyban voltak a koalíciós kormányok. Mivel az országok többségében kiigazításoktól függetlenül is többpárti kormány müködött, így nem meglepő, hogy a szóban forgó periódusban is ez a kormányformáció volt a felelős a közpénzügyek rendbetételéért. A brit, a svéd és a portugál kiigazításokra volt jellemző, hogy egypárti kormány hajtotta végre a költségvetési intézkedéseket, tehát a vizsgált tíz ország közül csak háromban vállalták fel egyedüli pártként a konszolidációk terheit. ${ }^{10}$ Mindemellett megállapítható, hogy a kiigazításokat levezénylő kormányfő igen gyakran fajsúlyos politikai szereplő volt, aki a választásokon több alkalommal is győzelemre segítette pártját.

\section{Konklúzió}

A tanulmány legfontosabb kérdése az volt, hogy milyen együttmozgás fedezhető fel a kiadásvezérelt költségvetési konszolidáció és a politikai folytonosság között. Bár egyértelmű választ nehéz adni a feltett kérdésre, hiszen a múltban megvizsgált országok rendkívül eltérő tradíciókkal és kiinduló állapottal rendelkeztek, illetve az egyes költségvetési eredmények mögött egyedi gazdasági és társadalmi folyamatok is meghúzódhatnak. Mégis a költségvetési kiigazítások kapcsán érdemes néhány általánosabb gazdaságpolitikai tanulságot levonnunk, amelyek hasznosak lehetnek a jövőre nézve (4. táblázat).

1. A vizsgált kiigazításokat tekintve számos hasonlóság és különbség körvonalazódik. A tanulságok közül a legszembetünőbb, hogy a sikeres költségvetési konszolidáció nem jár együtt a politikai folytonosság megszakadásával A 4. táblázatban szereplö tíz ország közül Belgium és Hollandia esetében a költségvetés markánsan kiadási oldalát érintő kiigazítás nem veszélyeztette a kormányfőt adó párt hatalmát, a költségvetési konszolidációt nem követte politikai átrendeződés. Ha a költségvetési konszolidációt végrehajtott összes országot vizsgáljuk, a kép némileg árnyaltabb: 29 választásból 17 esetben a kormányfőt adó párt a kiigazítás ellenére képes volt megtartani a pozícióját; 12 esetben azonban nem folytathatta tovább a munkáját. ${ }^{11}$

\footnotetext{
${ }^{10}$ A strukturális reformok véghezviteléhez elengedhetetlen az átalakítások társadalmi támogatottsága, amelyet egy széles bázison nyugvó koalíciós kormány feltételezhetően könnyebben tud biztosítani. Ezen hipotézis igazolása további vizsgálatokat igényel.

${ }^{11}$ A politikai változás ebben az esetben is arra utal, hogy a kiigazítás időszakában a kormányfő pártja képes volt-e megtartani a kormányfői pozíciót az újabb parlamenti ciklusban.
} 
4. táblázat

Politikai változások a kiadásvezérelt költségvetési kiigazítások tükrében

\begin{tabular}{lcc}
\hline & Változatlan folytatás & Változás a folytatásban \\
\hline Ausztria & 4 & 2 \\
Belgium & 3 & - \\
Egyesült Királyság & 1 & 2 \\
Finnország & - & 1 \\
Németország & 1 & 2 \\
Írország & 1 & 2 \\
Hollandia & 2 & - \\
Portugália & 2 & 1 \\
Spanyolország & - & 1 \\
Svédország & 3 & 1 \\
\hline Összesen & 17 & 12 \\
\hline
\end{tabular}

Forrás: Nemzetközi Valutaalap, Európai Bizottság, Nohlen-Stöver [2010].

2. A kiadásvezérelt kiigazítást végrehajtó országok többsége kettő, illetve három konszolidáción is átesett, tehát nem tűnik úgy, hogy az érintett országok döntéshozói tanulnak a múlt hibáiból. Ennek okainak feltárása mélyebb vizsgálatot igényel.

3. A tanulmány alapvetően a költségvetési egyenleg javulása felől világított rá néhány fontos összefüggésre. Az egyes országok kiigazításait azonban legalább két, az elemzés által nem tárgyalt lényegi komponens is befolyásolja. Egyrészt szükíti a gazdaságpolitika lehetőségét, ha egyszerre több ország kerül bajba (Blanchard-Leigh [2013]). Másrészt, ha a költségvetési egyenleg javulása mögött könyvelési trükkök húzódnak meg, akkor az a hitelesség csökkenésén keresztül hosszabb távon komoly károkat okoz (Kopits-Craig [1998], Koen-van den Noord [2005]).

4. Fontos megjegyezni, hogy az elemzés nem terjedt ki a költségvetési konszolidációk egyes összetevőire. Feltételezhető azonban, hogy a foglalkoztatottság, illetve a beruházások szintjét is nagymértékben befolyásolja, hogy a konszolidáció során miképpen alakul a költségvetés kiadásoldali szerkezete. Aligha kétséges, hogy a szerkezeti reformok középpontba állítása meghatározó szerepet játszik a fenntartható költségvetési pálya kialakításában (MNB [2006]).

\section{Hivatkozások}

Alesina, A.-Ardagna, S. [1998]: Tales of fiscal adjustment. Economic Policy, Vol. 13. Vol. 27. 488-545. o. http://dx.doi.org/10.1111/1468-0327.00039.

Alesina, A.-Ardagna, S.-Perotti, R.-Schiantarelli, F. [2002]: Fiscal policy, profits, and investment. American Economic Review, Vol. 92. No. 3. 571-589. o. http://dx.doi. org/10.1257/00028280260136255. 
Alesina, A.-Perotti, R. [1995]: Fiscal expansions and adjustments in OECD countries. Discussion Paper, No. 754.

Alesina, A.-Perotti, R. [1996]: Fiscal adjustments in OECD countries: composition and macroeconomic effects. NBER Working Paper, No. 5730. http://dx.doi.org/10.3386/ w5730.

Alesina, A.-Perotti, R.-Tavares, J.-Obstfeld, M.-Eichengreen, B. [1998]: The political economy of fiscal adjustments. Brookings Papers on Economic Activity, No. 1. 197-266. o. http://dx.doi.org/10.2307/2534672.

Blanchard, O.-Leigh, D. [2013]: Growth Forecast Errors and Fiscal Multipliers. IMF Working Paper, 13. http://dx.doi.org/10.5089/9781475576443.001.

Briotti, M. G. [2004]: Fiscal adjustment between 1991 and 2002: stylised facts and policy implications. Occasional Paper Series, No. 9. European Central Bank, Frankfurt.

CEMI [2006]: Makroegyensúly és gazdasági növekedés. Central European Management Intelligence, Budapest.

Devries, P.-Guajardo, J.-Leigh, D.-Pescatori, A. [2011]: A new action-based dataset of fiscal consolidation. IMF Working Paper, 11. http://dx.doi.org/10.5089/9781455264407.001.

Giudice, G.-Turrini, A.-Veld, J. [2003]: Can fiscal consolidations be expansionary in the EU? Ex-post evidence and ex-ante analysis. Európai Bizottság, Brüsszel.

Hoffmann Minály-P. Kiss Gábor [2010]: A statisztikai deficittől az átmeneti hatásoktól megtisztított államháztartási egyenlegig. MNB-szemle, 7-16. o. https://www.mnb.hu/ letoltes/hoffman-pkiss.pdf.

KÁRMÁn ANDRÁs [2008]: A magyar költségvetés kiadási szerkezete nemzetközi összevetésben. Hitelintézeti Szemle, 7. évf. 6. sz. 665-677. o.

Koen, V.-van den Noord, P. [2005]: Fiscal Gimmickry in Europe; one-off measures and creative accounting. OECD Working Papers, No. 417. http://dx.doi.org/10.1787/237714513517.

Kopits, G.-Craig, J. [1998]: Transparency in Government Operations. IMF Occasional Paper, No. 158. http://dx.doi.org/10.5089/9781557756978.084.

LÁmfalussy SÁndor [2008]: Pénzügyi válságok a fejlődő országokban. Akadémia Kiadó, Budapest.

McDermott, C. J.-Wescott R. F. [1996]: An empirical analysis of fiscal adjustments. IMF Working Paper, 96. http://dx.doi.org/10.5089/9781451965957.001.

MNB [2006]: Elemzés a konvergenciafolyamatokról. Magyar Nemzeti Bank, Budapest, https://www.mnb.hu/letoltes/konvjel-20061218-hu.pdf.

Nohlen, D.-Stöver, P. (szerk.) [2010]: Elections in Europe: A Data Handbook. Nomos, Baden-Baden, http://dx.doi.org/10.5771/9783845223414.

Perotti, R. [1996]: Fiscal Consolidation in Europe: Composition Matters. American Economic Review, Vol. 86. No. 2. 105-110. o.

Rzonca, A.-Cizkowitz, P. [2005]: Non-keynesian effects of fiscal contraction in new member states. ECB. Working Paper Series, No. 519.

Szemere RóBerT-P. Kiss GÁBor [2011]: Almát körtével? A négy visegrádi ország állami újraelosztásának összehasonlítása, 1995-2010. MNB-tanulmányok, 99. https://www.mnb. hu/letoltes/mt99.pdf.

TANZI, V. [1995]: Government role and the efficiency of policy instruments. IMF Working Paper, 95. http://dx.doi.org/10.5089/9781451852349.001.

Von Hagen, J.-Hallet, A. H.-Strauch, R. [2001]: Budgetary consolidation in EMU. European Communities, Economic Papers. No. 148. 